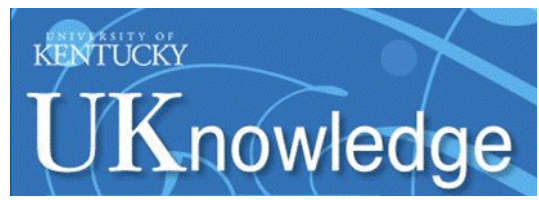

University of Kentucky

UKnowledge

Educational Policy Studies and Evaluation Faculty Publications

$9-21-2020$

\title{
A Digital Ethnography of Teach for America: Analysis of Counternarrative from the Truth for America Podcast
}

\author{
Julian Vasquez Heilig \\ University of Kentucky, j.vh@uky.edu \\ T. Jameson Brewer \\ University of North Georgia \\ Amber K. Kim \\ Miguel Sanchez \\ California State University, Sacramento
}

Follow this and additional works at: https://uknowledge.uky.edu/epe_facpub

Part of the Educational Assessment, Evaluation, and Research Commons

Right click to open a feedback form in a new tab to let us know how this document benefits you.

\section{Repository Citation}

Vasquez Heilig, Julian; Brewer, T. Jameson; Kim, Amber K.; and Sanchez, Miguel, "A Digital Ethnography of Teach for America: Analysis of Counternarrative from the Truth for America Podcast" (2020). Educational Policy Studies and Evaluation Faculty Publications. 11.

https://uknowledge.uky.edu/epe_facpub/11

This Article is brought to you for free and open access by the Educational Policy Studies and Evaluation at UKnowledge. It has been accepted for inclusion in Educational Policy Studies and Evaluation Faculty Publications by an authorized administrator of UKnowledge. For more information, please contact UKnowledge@lsv.uky.edu. 


\section{A Digital Ethnography of Teach for America: Analysis of Counternarrative from the Truth for America Podcast}

\section{Digital Object Identifier (DOI)}

https://doi.org/10.1177/0042085920953880

Notes/Citation Information

Published in Urban Education, v. 56, issue 4.

(c) 2020 The Authors

The copyright holder has granted the permission to post the article here.

The document available for download is the authors' post-peer-review final draft of the article. 


\begin{abstract}
To analyze the counternarrative in the public discourse surrounding Teach For America (TFA), this paper represents the first digital ethnography in education policy. We conduct a qualitative analysis of Truth For America, an education policy podcast. We found four overarching themes that arose from conversations with respondents: (1) problematic practice, preparation, and pedagogy; (2) concerns linked to critiquing TFA and the organization's responses to that critique; (3) issues related to race and diversity; and (4) disconcerting funding practices and political power. We conclude by discussing the implications of how individual-level stakeholder experiences inform the public discourse about TFA.
\end{abstract}

Keywords: Teach For America, Digital Ethnography, Counternarrative, Education Policy, Privatization, Philanthropy, Education Reform 


\section{A Digital Ethnography of Teach For America: Analysis of Counternarrative from the Truth For America Podcast}

Teach For America (TFA), the nation's largest and most discussed alternative teacher certification organization, sends under-qualified teachers into urban and rural schools that are arguably the most under-resourced schools in the United States (Brewer, 2014b; CrawfordGarrett, 2013; Darling-Hammond, Holtzman, Gatlin, \& Vasquez Heilig, 2005; Labaree, 2010; Lahann \& Reagan, 2011; Vasquez Heilig \& Jez, 2010, 2014). TFA's stated mission is to end educational inequity for low-income students (Vasquez Heilig, Cole, \& Springel, 2011). Their vision states "one day all children will have the opportunity to attain an excellent education" (Kopp, 2011, p. 12). The organization seeks to achieve its vision by recruiting, training, and placing college graduates - primarily untrained teachers - in America's poorest rural and urban school districts for a two-year commitment (Farr, 2010).

TFA's impact on domestic education policy and school-level practices are far more impactful than what would be expected from an organization that provides less than one-percent of the total teaching force (Laczko-Kerr \& Berliner, 2002; Vasquez Heilig \& Jez, 2010, Vasquez Heilig, Brewer, \& White, 2018). TFA's impact has also expanded globally through Teach For All (TFAll), the international export of TFA (Brewer, deMarrais, \& McFaden, 2020; La Londe, Brewer, \& Lubienski, 2015). Considering the peer-reviewed research examining TFA, the replication of fast-entry and short-term teaching worldwide should be a cause of examination for policymakers domestically and internationally (Vasquez Heilig \& Jez, 2014). Given the ideological and limited theoretical approach the organization takes towards recruitment and training, there remains a significant question about the impact that TFA/TFAll have on educational outcomes (Darling-Hammond, Holtzman, Gatlin, \& Vasquez Heilig, 2005). 
Grounded firmly in the largely-held belief that public schools in the United States have 'failed' and that 'bad teachers' are to blame, TFA from its inception has sought to attend to either a real, perceived, or manufactured teacher shortage (Brewer, Kretchmar, Sondel, Ishmael, \& Manfra, 2016) by enticing students from the top universities in the United States to volunteer teach for two years in low-income urban and rural schools - much like service in the Peace Corps (Vasquez Heilig and Jez, 2010). Appealing to the idealism of young do-gooders, TFA has by all accounts successfully reframed the profession of teaching as a non-profession of technocratic skills that can be learned 'on the job' and then discarded prior to mastery (Brewer \& Cody, 2014; McCarthy, 1998; Veltri, 2010).

The real focus of TFA, as it were, is less on training teachers and more on the production of alumni leaders who rely on their two years of teaching as providing evidence of pedagogical expertise (Veltri, 2012). Critical perspectives have included the critiques that alumni of TFA use this "manufactured expertise" (Brewer, 2016a) to move into policy making and school leadership positions where they are able to reinforce TFA's training and hiring model, suppress dissent, utilize problematic approaches to pedagogy and classroom management, and leverage funding and political capital to expand neoliberal educational reform (Cersonsky, 2013; deMarrais, Lewis, \& Wenner, 2013; Hartman, 2011; Sommer, 2014).

\section{A New Mode of Research}

The state of growth and importance of websites, blogs, forums, and social networking sites are contributing to the dissemination and creation of knowledge, however, these forums have typically been neglected by conventional research methodologies. More specifically, a growing number of people are now listening to podcasts. For example, survey data from Edison Research has shown that Americans listen to 21 million hours of podcasts every day (Willens, 
2015). According to Pew Research Center (2016), 21\% of Americans age 12 or older say they have listened to a podcast in the past month. They also report that $36 \%$ of American have ever listened to a podcast — doubling since 2008. As a result, many conversations in the public have shifted to digital forums that are both written and audio.

As public interactions about education increasingly move online, it is imperative that we respond with innovative research methods. Murthy (2008) argued that new media and digital forms of 'old media' are additional and valuable sources of data for research. For the novice and expert alike, the combination of participant observation with digital research methods into a 'multimodal ethnography' (Dicks, Soyinka \& Coffey, 2006) may provide a fuller, more comprehensive account. This is especially true with the inclusion of conflictual or ambiguous data from social networking sites, anonymous chat rooms, blogs and paid media marketing (Murthy, 2008).

Traditional ethnography, often employing participant observation (Angrosino, 2008; Rapley, 2009), seeks to understand meanings, meaning making — particularly as it filters through culture(s), while offering interpretations (Geertz, 1973, 1988). Coles and Thomson, in summarizing the work of Mills and Morton (2013), suggested that ethnography can take an "intuitive and experimental" approach to understanding by "assum[ing] an interpretive position, understanding ethnography as a process of taking back and forth between theoretical concepts and empirical materials" (Coles \& Thomson, 2016, p. 254). Along those lines— and in step with the current technological and information age — digital ethnography is a new form of research that not only allows the researcher to observe from the point of view of the subject of the study, but also allows readers to listen to respondents' voices in a publicly available podcast in 
perpetuity. In essence, the public can triangulate the research by validating the data and interpretations via social cross verification.

To understand the counternarrative in the public discourse surrounding TFA, this paper represents what we believe is the first digital ethnography in education policy. We conduct a qualitative analysis of the education policy podcast entitled Truth For America. Truth For America is a podcast that focuses on providing voice to TFA alums, educators, parents, students, and other key stakeholders. Truth For America is co-hosted by Julian Vasquez Heilig and T. Jameson Brewer. As of Spring 2018, there were seventeen podcast episodes. The podcast has had about 30,000 listeners across all digital platforms including YouTube, iTunes, Soundcloud, Stitcher and other podcast service platforms.

In this paper, we highlight the counternarrative about TFA at the individual level by analyzing the voices of stakeholders who have first-hand experience with TFA. The digital ethnography analysis focuses on the first 12 episodes and examines how 23 individuals describe their experiences with TFA. As is the case with ethnography, we seek to allow the voices of participants to speak the loudest and provide rich insight draped against a discussion of how the lived experiences of 23 TFA corps members, alums, and key stakeholders are discursive artifacts in the domestic and international education reform movement. We seek to answer the question: What insight do critical stakeholders have about their experience with TFA and whether the organization undermines quality and equity in the education of students?

We begin with a synthesis of the pertinent literature on educating for transformational equity and social justice to establish a background of understanding upon which to examine the shared experiences of podcast participants. Next we discuss the role of counternarrative for conceptualizing the current educational policy environment driven by TFA and other education 
reformers. In the findings section, we report the four overarching themes that arose from conversations with respondents: (1) problematic practice, preparation, and pedagogy; (2) concerns linked to critiquing TFA and the organization's responses to that critique; (3) problematic issues related to race and diversity; and (4) disconcerting funding practices and the political power. We conclude by discussing the implications of how individual-level stakeholder experiences inform the public discourse about TFA and fit into the larger conversation about education reform.

\section{Teach For America and Educating for Equity}

During their two years, TFA corps members (CMs) — who are historically majority White - are supposed to level the playing field for their students who are predominately lowincome students of color. This means that CMs are expected to ensure that their students acquire the same academic skills and knowledge as their more affluent White counterparts (Farr, 2010; Labaree, 2010). Alumni are expected to promote the same dispositions, practices, and academic outcomes from whatever leadership positions they land post corps experience. Together, current CMs and alumni are meant to ensure that all children have the opportunity to obtain the type of education historically reserved for White suburban middle class students.

Reviews of the overall effectiveness of TFA — its ability to level the playing field and close the achievement gap — find mixed results (Clark, Isenberg, Liu, Makowski, \& Zukiewicz, 2015; Glazerman, Mayer, \& Decker, 2006; Darling-Hammond, Holtzman, Gatlin, \& Vasquez Heilig, 2005). What is not debatable, however, is TFA's power and influence. Since inception, TFA has been an out-sized actor in education, receiving billions from philanthropic donors (deMarrias, Lewis, \& Wenner, 2013), as well as considerable federal and state funding (Vasquez Heilig \& Jez, 2010, 2014). Drawing from such deep financial coffers, TFA has been able to 
fundamentally impact the landscape of education reform and the accepted effective practices and policies of education by recruiting and shaping educational and political leaders (Brooks \& Greene, 2013; Gutmann, 2013; Veltri, 2012).

Nieto (1999) reminded educators that we need to challenge pedagogies that prepare students merely to fit into an unjust society and that we need to prepare students to challenge the inequities that undergird our society. This is not just limited to students. Educators, leaders, policy makers must not perpetuate the status quo and prepare people to fit into unjust world; they must challenge inequity and oppression/suppression at all levels. These outcomes taken together mean that students, and subsequently teachers who facilitate this, are prepared to change the game, not merely play it.

From TFA's inception, critics raised concerns about the potential for CMs to view cultural differences as a deficit holding student back from achieving on high-stake testing and at the root of school discipline issues instead of a source of strength (Darling Hammond 1994; Popkewitz 1995, 1998). Darling Hammond (1994) charged TFA CMs with racial insensitivity, and an inability to understand and identify with the children and communities they serve. She posited that TFA's training and philosophy positions their students "others" and outside the “normal." Many authors share Darling Hammond's concerns, and an increasing large chorus of vocal critics have raised questions regarding the deficit-based, savior mentalities of TFA CMs (Brooks \& Greene, 2013; Labaree, 2010; Matsui, 2015; Ruiz Bybee, 2013; Stern \& Johnston, 2013).

Searching the literature for investigations of cultural competence within the TFA, the authors found one case study of a single year as a CM (Kwock Hu, 2009). The study showed that even a CM who expressed a desire for educational equity and a belief in CRP, did not 
demonstrate this desire and belief in her instructional practice. Additionally, Veltri (2008) examined CMs' experiences and familiarity with their students' cultural backgrounds, finding it to be limited. To quote: "Eighty-five percent of TFA participants noted that their academic frame of reference, geographical region they called home, and cultural background were markedly different from their students" (p. 530). CMs fit a different social class than their students, and view their corps experience (and their students) from their own personal, monocultural lens; they were unable to move to a pluralistic worldview that would be more appropriate pedagogical approach for the success of their diverse students.

Researchers have repeatedly called for TFA CMs to be less "colorblind" and to possess more critical consciousness (Brooks \& Greene, 2013; Lahann \& Mitescu Reagan, 2011; Ruiz Bybee, 2013; Stern \& Johnston, 2013). While research on the topic is limited, Heinike and Cameron (2011) interviewed former TFA teachers in Arizona to explore their beliefs and practices in regards to the controversial "English Only" Language Policy. They state, "[TFA] teachers in this study openly critiqued the language policy and appropriated the policy in their own ways to meet the needs of their students in the classroom..." which would demand colorawareness and critical consciousness of the eight teachers studied (seven White) (p. 501). These results highlight the independence of CMs and the potential, at least in an extreme setting, for a critical consciousness. As a predominantly White organization, placing White CMs in communities of color, surprisingly not a single study evaluates the White identity development of CMs. While not empirically investigated, a number of informal critiques of TFA CMs being White "missionaries" sent over to "save" poor people of color do exist (e.g. Brooks \& Greene, 2013; Labaree, 2010; Stern \& Johnston, 2013). 
In sum, educating for transformational equity and social justice is essential for educational equity. This study seeks to understand whether these competencies, attitudes, and beliefs are pertinent to TFA the reality that the organization perpetuates. Considering TFA's outsized influence and power, the experiences of stakeholder with the organization make it an important focus of research. As a result, this study seeks to examine the interrelated issues of educational equity within the experiences of TFA stakeholders.

\section{Counternarrative}

The second tenet of Critical Race Theory (CRT) is that experiential knowledge through storytelling is a powerful tool that provides voice to those that are often silenced. Through storytelling, historically marginalized individuals are able to provide essential context to the experience of oppression and systematic racism (Ladson-Billings, 2010). Storytelling is an important tool as critical race theorist and social justice change agents work to dismantle oppressive systems as individuals are able to bring a "presumed competence" (p. 10) to speak about race and oppression (Delgado \& Stefancic, 2012).

While dominant story of any large, influential organization can be read and understood, there are most often teams of people, including leaders and marketing professionals, whose job it is to spin, narrate, document, and promote the official positive narrative. Counternarratives function as a constructive critique to the dominant discourse. They are essentially "little stories" of individuals and groups of people whose knowledge and histories have been excluded from the telling of official narratives (Giroux, 1996, p. 2). These localized "little stories" have the power to interrupt and raise questions about the polished grandiosity of a dominant narrative. Counternarratives provide a more truthful and complete representation of reality. The primary purpose of counternarratives is not to negate the dominant narrative, although this may occur; the 
primary purpose is to construct a fuller historical account of events, a more complex understanding of the current reality, and a messier telling of the impacts.

It is also important to note that TFA has historically refused data and corps member access to researchers who are not willing to sign agreements that assure the organization that research will not be critical of the organization. Without such agreements, researchers are not able to gain access to TFA corps members or the data collected by the organization.

Furthermore, a guest on the Truth For America podcast revealed that TFA often requires former employees to sign non-disclosure agreements to prohibit them from criticizing the organization after their departure (Wirth, 2017). These maneuvers by TFA have led to a dearth of readily available respondents for research that has the potential to inform public and directly led to a paucity of research that provides voice to counternarratives about TFA in the body of peerreviewed research. As a result, the digital ethnography approach creates a new opportunity to attract respondents as individuals come into contact with the podcast online and develop an interest in telling their story. Considering the fairly wide reach of a podcast, access to respondents nationally and internationally offers the unique opportunity to reveal additional information not previously available in the public discourse or in the research literature.

We are aware of one prior chapter that utilized counternarratives to provide a conceptual framework for analysis of TFA (Muñoz, Vasquez Heilig, \& Del Real, 2019). We build on this prior work by using digital ethnography to analyze counternarratives to establish a contrasting critical narrative. We do not study the efficacy of the program relative to the paid marketing efforts by TFA that seek to generate the positive public image that their inexperienced teachers are highly successful (Joseph, 2014). However, the respondents' counternarrative does inform the field about TFA's official outward-facing political narrative and positive framing found 
online and in media materials and actions. Our method allows us to interrogate the notion of equity and the implied outcomes of liberation. We seek in this paper to steep the reader in TFA counternarratives using an informed lens of equity. As a result, we use the voices of stakeholders and TFA affiliated individuals in the Truth For America podcast to more fully analyze the impact that the organization is having on students, teachers, CMs, schools, and education policy across the United States and world. This process of telling can potentially lead to the emergence of new practices and policy (Foucault, 1977, p. 9).

\section{Methods}

This study utilized digital ethnographic research to gather perceptions of TFA corps members, alums and other education stakeholders. To understand and document the experience of CMs, TFA alums and other education stakeholders (journalists, educators, researchers) that have interacted with TFA CMs, the research presented involved in-depth public interviews with 23 individuals. The approach to the respondents is what we are calling a digital snowball sample. As the podcast spread across the internet, listeners approached the hosts to participate in the podcast. Essentially, the digital reach of the podcast exposed and attracted members to the sample. As a result of the digital snowball, most of the podcast guests were focused on counternarrative - stories and narratives that splinter widely accepted truths about TFA as well as the value of TFA and the knowledge produced by and within TFA. Once respondents contacted the hosts, permission was sought from the individuals to join the podcast. Twentythree individuals agreed participate in the first twelve episodes of the podcast. Eight individuals eventually declined or did not respond to repeated e-mail or phone calls. For privacy and confidentiality, some individuals chose to participate in the podcast using pseudonyms. 
Podcast conversations were conducted over a span of two years. All of the podcasts were semistructured and lasted between 30 minutes and approximately one hour. Interviews with participants took place in secluded and live settings. For example, in three cases, the interviews were recorded live at education oriented conferences (Network for Public Education and Save our Schools). The podcasts were edited using Audacity software for content and engineered for sound quality. The podcasts usually featured between two and five individuals and were typically taped on the weekend and evenings. The informants in this study were two current TFA teachers, ten TFA alums, and 11 education stakeholders (see Table 1).

Table 1. Truth For America Podcast Participants [insert here]

\section{Data Analysis}

The podcast-based qualitative research involved interviews with respondents that into contextualize their experiences with TFA. Comparative analysis is grounded in flexibility as the research evolves (Glaser, 1992). As a result, the podcasts initially utilized a rubric of open-ended questions identified in the literature to understand TFA from an empirical perspective. However, as the research commenced, questions were eliminated in favor of others that arose during informal conversations with participants that occurred before taping. In essence, to gather richer data, the research was grounded in emerging themes revealed by the participants.

Charmaz (2005) suggested that constant comparative analysis stimulates the inductivity necessary to illuminate social justice issues that otherwise might be neglected in the research process. For example, whether TFA is playing an outsized role in privatization and private control of public education may be unobservable and inaccessible when observing TFA marketing materials or the public discourse in traditional media. The flexibility of qualitative comparative analysis of a podcast empowers researchers to move beyond surface observations to 
delve deeper into phenomena of interest and counternarrative with informants as they arise during the public and digital conversations.

A graduate student transcribed all of the interviews. The transcripts were then analyzed using the constant comparative method (Patton, 1990). We coded phrases that had meaning in relation to the main topics and purposes of the study. Next, we sought to define axial relationships to identify consistent emerging themes within the phrase coding (Borgatti, 2005). After coding the interviews, we wrote thematic summaries to create the descriptions of participants' motives and circumstances that are presented in the Findings section. To check the authenticity of the work and moderate the validity threats of description and researcher bias, researchers conducted member checks by examining the data, helping to develop the topics, codes, emerging themes, and participating in online group sessions to review the completed manuscript (See Appendix A). Furthermore, as discussed above, digital ethnography not only allows the researcher to analyze data, but also allows readers to listen to respondents' voices and triangulate the research by validating the data and interpretations via social cross verification.

\section{Analysis of Counternarrative in the Truth For America Podcast}

Across the twelve podcast episodes included in this analysis, we identified four overarching themes that arose from organic conversations with guests: (1) practice, preparation, and pedagogy; (2) concerns linked to critiquing TFA and the organization's responses to that critique; (3) problematic issues related to race and diversity; and (4) funding practices and the political power that first provides the funding but then, in turn, reinforces the political capital that TFA wields. We take up each of these themes, in turn, now. 


\section{Practice, Preparation, and Pedagogy}

A fundamental characteristic of TFA is not only the organization's fast-entry training paradigm, but that it conceptualizes teaching as a short-term position grounded in the "discourse of bourgeois social volunteerism" (McCarthy, 1998, p. 142). This conception of teaching as short-term and somewhere along the way the ability to develop manufactured educational expertise reinforces a systemic reduction in actual experience of not only teachers but, in turn, administrators and other district-level positions (Brewer, 2016a). Marta, a high school principal in Texas, was the first guest on the podcast and discussed this phenomenon pointing out that, Out of forty that we hired, maybe we had one or two after the second year ... another problem that comes with Teach For America is because they have that push from the district, we have large numbers. We have a situation where the whole-entire department is new, and that is not a healthy situation. We all started somewhere but when I started, the teacher to my left and the teacher to my right were very good teachers. So, I was able to reach out and they were able to help me out. Now, everyone is new; so, nobody knows what they are doing, and they don't have anywhere to go to ask for the help. (Marta, Principal Speaks, 2016, January 13)

Minimal training and minimal experience in teaching is not a symptom of TFA, it is a feature. TFA corps members are mainly serving a short-term contract that, as a result, do not have much accountability with the district or with the students. Similar to the concerns expressed by Marta, Tiffany shared that,

I kept hearing time and time again from Teach For America, 'it's going to be hard but you just have to try harder.' I don't think that is a very sustainable approach to 
cultivating teachers, which I think is how Teach For America portrays itself. It was not an ideal situation. There were not any veteran teachers around to ask questions. What was normal, or what should happen, or if there were any problems; there wasn't always someone that we could go to. (Tiffany, TFA FirstYear Experience, 2016, April 29)

During the conversation with Tracy Dell'Angela, a blogger for Education Post, the issue of experience and training arose- particularly in relation to outcomes. She suggested, The totality of Teach For America studies is not showing that Teach For America is doing worse, they are doing roughly the same or better; depending on the context, depending on the city, depending on the subject that they are being taught. Now, I'm not going to disagree that a teacher in the first couple of years, across the board, whether they are traditionally trained or whether they are trained by Teach For America, it's just a different hiring model. The reality is, you are not good at what you do, until you do it for a couple of years. I went through that process while I was a professional starting out. I thought that I was going to set the world on fire, and I had a lot to learn in two years. I'm not arguing that these teachers (Teach For America's) are better than your best pros after ten years. (Dell'Angela, 2016b, February 8)

It was notable that Dell'Angela admits that it takes multiple years to hone the requisite skills for teaching. Yet, to support her vehement defense of TFA, she relayed her daughter was considering joining TFA (Dell'Angela, 2016a). She ignores the irony that a predominant feature of TFA is the lack of experience, a two-year teaching commitment, then departure. Again, Marta noted about her experience in Houston, 
I was not a master teacher until after I had two-three-four years in the classroom. The problem is that they are saying that they are ready to go after five weeks, and after the two years when they would be starting to become half way proficient, they are leaving. (Marta, Principal Speaks, 2016, January 13)

If corps members are able to produce equal or better results on achievement scores as measured by standardized testing it would logically suggest that teacher training is almost entirely unnecessary if someone with 18 hours of student teaching can produce the same results as compared to someone with a year of student teaching and multiple years of education-based coursework. In fact, prior research on TFA has demonstrated that this premise is not the case (Darling-Hammond, Holtzman, Gatlin, \& Vasquez Heilig, 2005). It is logical that the predominance of peer-reviewed research demonstrates that TFA corps members, with such limited training and only 18 hours of student teaching (Brewer, 2014a), do not outperform traditionally certified, veteran teachers.

There are two issues of interest here: (1) to what extent are test scores a reliable measure of good teaching; and (2) if gains on tests exist, to what extent are they illusory given the impact that a drill-and-kill approach might have on test outcomes? To the extent that TFA corps members are able to produce equal or better test scores as a result of an incessant drill-and-kill pedagogy, then TFA has become the very prominent adherent of what is certainly the very worst practice in teaching (Veltri, 2008). Yet, while it is widely understood that teachers get better over time, the very nature of the TFA model may undermine any positives that exist given the high rate of turnover endemic to the program (Vasquez Heilig \& Jez, 2014). In fact, the turnover rate for traditionally certified teachers after five years is usually somewhere between forty and fifty percent and yet, the attrition rate of TFA teachers can approach nearly 80\%. (Darling-Hammond, 
Holtzman, Gatlin, \& Vasquez Heilig, 2005). Marta spoke about this issue at her Houston high school noting that,

They [TFA] would tell you what their plan is. I'm going to be here two years and then I'm going to medical school. I'm going to be here and then I'm going to look for this and that, in the private sector. So, they come with a plan and they will tell you. I think that there is a flaw in their recruiting process right there. Who is going to master a profession that is not for the long run, that they are not invested on. They are not asked to do anything that is not going to be tax-for in the future. Who would give their best? (Marta, Principal Speaks, 2016, January 13).

Among the 145 hours of total training that corps members receive during the 5-week summer institute, those corps members who are scheduled to teach special education receive approximately 2 hours of training in all things special education (Scott, 2017). The problem, it would seem, is that a model for training teachers in the practice, legality, and delivery of special educational services in a couple of hours magnifies the feelings of underpreparedness that corps members report. Rebecca (a pseudonym due to the request of the individual to protect her identity due to her discomfort with TFA knowing her name) shared that even despite telling TFA during her interview that she would not be comfortable teaching special education that she was nonetheless hired to teach special education. She shared,

During the interview a person from Teach For America asked me, do you have any experience working with special education? ... I don't want to be place in special education was my response. Later, I received a letter from Teach For America, congratulations Rebecca! You are in the city, your home city, and by the way, you are in special education. If you said that you don't want special 
education, then you are not in the program anymore. And I had the most incredible experience; it was wonderful to work with the children in the class. But I had absolutely zero support from Teach For America. I had no idea of what I supposed to do in the first day. All the teaching that help me to get my students from a failing level to an honor level, were literally exercises that my father and I used to do to help me out. So, I had not practices from Teach For America that help me in the classroom. (Rebecca, Not Special Education, 2016, March 18) Ian Scott, who taught special education through TFA at a large charter school network in Los Angeles, shared the following problematic critique of his placement and training experience, I went into my first day as a teacher not knowing how to write an IEP, not knowing the basics of special education law; no-knowing any of these things that someone needs to be a functioning special education teacher, who is able to advocate for their students' rights and educational rights. And this is very important because the school where I was placed at, for the first semester that I was there, I was the special education department. I was the only special education teacher in the school and I had not training in how to do the job that I was assign to do." (Scott, Charters and Special Education, 2017, February 27). TFA's questionable approach to special education is not limited to how it trains corps members who become special education teachers but becomes highly questionable when enacted with TFA's charter school partners.

When it comes to what charter education is doing, it's the opposite of what they said that they were going to do, which is to provide choice to parents. They are doing one-size fits all approach to special education. There are not many 
opportunities for meaningful differentiation, meaningful access to different least restrictive environment; and they are presented to parents as take it or leave it sort of offer. We are talking about the whole purpose behind charter schools, which is to provide choice. There has to be a meaningful choice for parents at the school level. And not, whether or not, I want to enroll my child at whatever charter school and take whatever they decide that they want to offer. Charter schools are not exempt from providing what is legally required from all public schools under the IDEA. As long as they continue to approach special education this way, they are acting against the stated mission of why charter schools were supposed to exist in the first place. (Scott, Charters and Special Education, 2017, February 27) Additionally, TFA's relationship and reliance on charter schools has grown in the last two decades to the point that the organization has relayed that about one third of their CMs are placed in charter schools. Ian relayed his perspective on the relationship between charter schools and TFA.

It's really hard for me to see Teach For America as separate from the charter schools movement. One of the earliest examples that I can think of, during induction, which is the welcome week in the summer [Institute]. They [TFA] have representatives from Parent Revolution there, to meet with corps members and brag about their work ... For anyone that doesn't know what Parent Revolution is, they are an organization that focuses heavily on, parents trigger laws in California that are designed to let schools be transformed. Which is basically taken over a traditionally public school, closing it down, get rid of the staff, and turn it over 
into charter provider ... This was consistent with my experience with Teach For America. (Scott, Charters and Special Education, 2017, February 27)

TFA provides the kind of workforce that charter schools need to function. In fact, the KIPP network of charters rely on TFA as a "ready supply of fresh blood that [is] required to sustain the martyrly commitment and performance standards that KIPP demands from teachers [65-hours of school related work per week]" (Horn, 2011, p. 88-89). When corps members have such limited time for training, the teaching of pedagogical methods and behavior management must by default be limited to a singular method that is presented as a one-size-fits-all recipeand in sites like KIPP, overly militarized. Grounded in Steven Farr's Teaching as Leadership (Farr, 2010) and the Academic Impact Model (Brewer, 2014a), corps members are not only expected to create long plans, the plans must be fully scripted. The plans are,

Fifteen to twenty-page lesson plans that core members have to deal with, literally scripted; where you are standing in the room, what you are going to say. The mindset is, let's approach teaching as this scripted recipe. I think that reinforces the idea that you don't really need a lot of experience in teaching to teach others how to do it because this (teaching) is just another technocratic skill. (Brewer, Not Special Education, 2016-b, March 18)

\section{Response by TFA to stakeholder critique}

Critique and criticism of TFA has a long documented history of being bed with pushback, marginalization, ad hominem attacks, and a general dismissiveness directed towards what the organization considers as detractors (Joseph, 2014). Given that TFA is firmly situated within the broader domestic and international neoliberal education reform, much of TFA's discourse is rooted in commonsensical language. That is, TFA is "doing good" because schools have "failed" 
and doing something that challenges the status quo and injects market-oriented competition must be good and must be working. Harkening back to naive idealism discussed above, Diane Ravitch expressed on the podcast that she,

...was invited to the 'Aspen Ideas festival' a few years ago to debate [Wendy Kopp]. And the Aspen Ideas Festival is totally completely dedicated to corporate reform of education. So, I was before an extremely hostile audience and I made the typical mistake that is something liberals do, which is, I kept using facts. But when you're debating Wendy Kopp facts won't matter because she says, 'we transform children's lives; we make change, it's working.' And no matter, how many facts I'd bring up but whether it was about New Orleans, New York, Washington or any other place; she'd say, 'we transform children's lives, we know it works because it's working,' and then everybody applauded. And I thought, is this how she got all those millions of dollars for those corporate executives? They just want to sit here, somebody sells them a line of baloney, and no one look at any spreadsheet to see what are the actual facts. (Ravitch, Ravitch et al. LIVE, 2016, April 22)

Ravitch's interaction with Kopp provides a telling artifact of the commonsensical language employed by TFA within the global education reform movement. The third episode of the podcast focused on the experiences of TFA alumni-turned-critics who were purposefully marginalized by the decision to give them a room at the back of the conference hall on the last day of the $25^{\text {th }}$ anniversary TFA Summit. The experiences described by the alumni guests in the third episode echo Ravitch's comments in that TFA defenders at the summit introduced straw man arguments of lofty idealism rather than committing to honest, open, and critical dialogue. 
Any critique of TFA - especially from its members and alumni - is either brushed off or met with harsh criticism by the organization and its most strident supporters (Joseph, 2014).

\section{Race and Diversity}

While TFA has sought to expand the number of non-White corps members within its program over the past few years, the organization has a legacy of employing a White savior mentality while enacting pedagogical and behavior expectations for students that align with White cultural assumptions of knowledge, achievement, and behavior (Matsui, 2015). Often these expectations are manifested as strict behaviorism that relies on militaristic discipline, ridicule, and dehumanization (Horn, 2011). Part of the neoliberal imaginary is to reduce students and teachers into quantifiable components for comparison and value-assignment. This, partnered with TFA's ideological understandings of education and teaching, result on a strong tendency to suggest that the best solution for students of color who are living in poverty is to simply get better test scores. Better test scores, as the logic goes, will afford the non-White student to rise above systemic poverty and live the 'good life' that is often showcased by way of the White corps member in front of the classroom who too will leave the community soon. Amber Kim, a TFA alum and University of Colorado Denver faculty member, suggested that,

But if they [TFA] keep defining educational equity as an achievement gap that poor-kids, and poor-kids of color have; they just don't have the kind of education that the White-elite have if that is the problem, they will always solve it in the same way, by giving poor-kids and poor-kids of color what white-people have.

(Kim, Ravitch et al. LIVE, 2016, April 22)

Kim went on to proffer, 
Like affluent people have, and that is a White-supremacist education. I don't want to give that to poor-kids, I don't want to give that to communities of color. I want to change that kind of education, and that involves critical pedagogy, that involves equity literacy, that involves positive cultural, and socio-cultural identity development. And Teach For America's teachers are not being trained, and no one's being trained in developing equity-literacy and positive socio-cultural identity for kids, who are not other than the dominant culture, and no one is teaching White affluent kids equity-literacy. So, if they don't have it, we will never end the oppression and that is the real problem; there is a real inequity in America, it's not the achievement gap. (Kim, Ravitch et al. LIVE, 2016, April 22) Jesse Hagopian, a TFA alum and a teacher leader of the 2013 Measure of Academic Progress (MAP) test boycott at Garfield High School in Seattle also told us that he, ...learned about what neglect and underfunding of the schools could look like, and the impact it had on the children. But in terms of my ability to teach them, or understand how that process worked in their neighborhood, I was unequipped. I would say that Teach For America's philosophy in terms of what they value is teaching to the test; I was told that's the approach to pedagogy. Then, the problem with that is, undoing institutional racism is not on the teaching of the test in the curriculum. (Hagopian, Racism? Diversity?, 2016, April 18)

Terrenda White, a TFA alum and University of Colorado Boulder education faculty member, pointed out that the dispositions and understandings of teachers who do not come from or share a historical connection to the communities in which they serve are likely unable to 
accomplish meaningful educative work that is culturally relevant and, like Kim's suggestion above, undermines the identity of students of color. She told us that, ...it matters to have a teacher who may be grounded in the community and have understanding of the history of racism; as how racism plays out in their community or some of the issues that their community is facing. So, local movements that have a relationship with teachers who may be connected to what's happening in New Orleans, and can speak to the cultural traditions and their neighborhood. I mean, how do you leverage? how do you have a culturally relevant pedagogical approach? When you don't have a sense of contact, history, and understanding of that community. (White, 2016, April 18)

Howland-Bolton, Detroit TFA alum and educator, also pointed out that, Change doesn't come from the outside, change does not look like a White college educated person, who has never been to the city before. Those are not the people that are well acquainted with the issues. Therefore, those are not the people who are going to be able to come with solutions that actually work. But by investing in that narrative, we actually perpetuate this damaging cycle of people believing that they cannot change what is in their communities. We put these teachers in front of kids and that sends a message. When you look at your teacher as this person who has been trained in an elite style of classroom management which is totally dehumanizing; uses proximity, intimidation, and volume, all these different tactics. (Howland-Bolton, 2016, July 13)

As a corps member reflecting on the racial impacts of TFA, Amber Kim suggested that it was her own "racism and classism" that was recruited into TFA and, 
...that it had grown, and it was used in Teach For America to hurt children, and to hurt communities. The biggest thing that I remember is not ever being taught, we always were using the words of equity, diversity, and inclusivity. But, we were never taught to question, what we were teaching, or how we were teaching. And that factories behavior narration, and scripted curriculums. And that did not feel right to me, and I started to feel the racism in the classes. (Kim, Ravitch et al. LIVE, 2016, April 22)

\section{Funding and Political Capital}

Researchers have identified TFA as a part of a larger cabal of education reform organizations heavily funded by policy patrons (Tompkins-Stange, 2016), that seek to privatize education and, in the process, exacerbate racial and class inequality while simultaneously propping up movements to standardize learning and outcomes measurements (deMarrais, Lewis, \& Wenner, 2013; Reckhow, 2013; Reckhow \& Snyder, 2014). With the assumption that test scores are the natural proxy for measuring quality of teaching and learning, education reform organizations like TFA concentrate their focus singularly on raising test scores. The goal, as it were, is to legitimize the myth of the failed school and justify the silver-bullet reform.

In the process, organizations that purport to be attending to test score improvement have become the darling of venture philanthropic donations that have exceeded hundreds of millions of dollars (deMarrais, Lewis, \& Wenner, 2013). And many of the alumni from TFA have tuned into this reality. Terrenda White noted, ...among corps members there is a considerable understanding that if we [TFA] can raise test-scores, that will legitimate more funding and private donations, as 
well as other initiatives that seem marginal and peripheral but enough to perhaps signal to some of us like myself who are concerned with other things. I think that they are doing a double approach. But unfortunately, this source of ramping-off or proving its existence, seek the test-score and the competitive drive seem to be the bigger focus, and I don't think that is going to change." (White, 2016, April 18) Appealing to the idealism of corps members, TFA has promoted itself as a civil rights organization while, in fact, it has been espousing educational policies of individualism, competition, and neoliberalism since its inception. Diane Ravitch pointed out during a podcast episode that she has, met many young people from TFA,

I've always been impressed by how idealistic they are, how committed they are, how much they want to make a difference in the world, and they're very bright. But what they haven't figured out is, they have been used by an organization [TFA] that is a tool of the right-wing effort to destroy public education and to destroy unions. Teach For America took fifty-million dollars from the Walton Foundation, I guess it's hard to turn down fifty million dollars from anyone. But the Walton Foundation specifically has as anti-union agenda and someone in one of our earlier workshops said that they fought the living wage if they really wanted to improve conditions for people living in this country; then, they would pay their employees a decent wage. (Ravitch, Ravitch et al. LIVE, 2016, April 22) Drawing considerable strength and power from its financial backers, TFA has been able to wield a considerable amount of political clout at the state and federal level - particularly when it comes to laws and rules surrounding teacher preparation and licensure requirements (Brewer, 
2016a; Brewer, et al., 2016). Howland-Bolton told us that TFA was able to get the state constitution amended to allow the program to re-enter the state. She noted that, They brought [in] Teach For America ten years before. Then, Teach For America got kicked out. And to bring Teach For America back, they had to change the state's constitution in order to reduce the necessary criteria for becoming a teacher; someone had to be certified to become a teacher, it was in the state's constitution. (Howland-Bolton, SOS! LIVE in DC, 2016, July 13)

The artifact of how much political capital TFA has at the state level was echoed at the federal level following the ruling in Renee v. Duncan (2010) and the amendment to NCLB to allow "teachers in training" to be classified as "highly-qualified" (Brewer, 2016a). Zeichner (2013) wrote,

In the summer of 2012, as the temporary amendment approached its expiration date, the debate intensified again about the broader definition of "highly qualified." Teach For America (TFA), charter networks, and other "reform" organizations pushed for the extension arguing that classrooms would be left without a teacher if Congress held firm to the original highly qualified teacher (HQT) standard of full certification. In reality, districts would still be permitted to hire teachers who were still in training, but they would need to distribute them more equitably and a plan would need to be developed to lessen their number over time. On the other side, over 90 civil rights, disability, grassroot community, and education organizations comprising the Coalition for Teaching Quality argued that the HQT amendment hides and perpetuates the disproportionate concentration of teachers-in-training in schools and classrooms serving low-income students, students of color, students with disabilities, English learners and rural students. 
The HQT amendment was extended for another year with the new requirement that the U.S. Department of Education collect data on the distribution of uncertified "highly qualified" teachers.

And while the reduction of state and federal requirements for teaching credentials have not all been a result of efforts by TFA, the ideology shares the same conclusion: that teaching is a technocratic skill, those that requires little to no actual training and preparation prior to entering the profession.

The changes across the educational policy landscape that have received so much philanthropic funding have happened under the guise of improving equity and opportunity for all students — particularly non-White and non-affluent students. Yet, the broader reform movement has, in fact, caused a considerable amount of damage to the very populations that the reforms purport to attend to. Jesse Hagopian suggested that, ...the model of Teach For America is so integrated into the larger privatization agenda. When you look at the way that Teach For America has served the expansion of charter schools, or supported charter schools, you have to think about the high-rates of push-out in those schools of students of color. The zerotolerance programs that have dramatically and disproportionately suspended students of color in those programs, are allowed to continue, by the larger apparatus support for reform that includes Teach For America. So, is not enough to just diversify a teaching force if you're supporting charter school programs that are disproportionately suspending students of color. I think that is fundamentally flawed. (Hagopian, Racism? Diversity?, 2016, April 18) 


\section{Discussion}

The counternarrative relayed in the podcast by respondents suggests that TFA has inserted additional problematic issues into the United States' most challenging school environments. These issues directly call into question the "training" CMs purportedly receive and the "teaching" they provide in the name of educational equity and social justice.

Furthermore, the respondents' voices - that readers of this paper can hear for themselves in the podcast episodes available in the various public online platforms — raise several important issues for discussion.

The public narrative promoted by TFA is that their CMs are properly prepared during the five week summer institute where they have received about 18 hours classroom training. The argument promoted by supporters of TFA is that their limited amount of preparation is sufficient - even more desirable than teachers trained by college and universities. (DarlingHammond, Holtzman, Gatlin, \& Vasquez Heilig, 2005). However, the respondents in the podcast by and large are in alignment with the predominance of previous research (Vasquez Heilig \& Jez, 2014) that has indicated that the summer institute does not adequately prepare CMs. Furthermore, prior research has found that the type of preparation that CMs receive is problematic in terms of inclusivity (Darling Hammond, 1994), focus on test preparation (Brewer, 2014a) and inappropriate disciplinary approaches (Anderson, 2013a, 2013b). Respondents in the podcast have triangulated prior research on the problematic practice, preparation and pedagogy that CMs receive before they enter some of the most challenging schools in the United States and underscored prior research that demonstrates that CMs express that they feel unprepared and it negatively impacts their students (Veltri, 2008). 
The podcast participants also reflected on TFA's response to critique and criticism. At the time of writing, TFA had not responded directly to the conversations in the podcast. However, supporters of TFA have retorted in social media and also approached the hosts to guest on the podcast. For example, Tracy Dell'Angela, a contributor to Education Post, reached out to the hosts via social media and participated in the second episode. Education Post is an online education reform oriented media organization that has received hundreds of thousands dollars from many of the same donors (i.e. Walton Family Foundation) that have also reportedly given large donations to TFA (Schneider, 2016). The approach utilized by Dell'Angela in the podcast was to deflect, ignore and minimize the critiques of the organization. This is the approach that TFA, many education reformers, and supporters have taken when faced with critiques from stakeholders and in the research literature (Joseph, 2014).

TFA has sought to reframe themselves as an organization that focuses on equity, inclusion and diversity. Considering their strongly stated of goal of educational equity, it is important to critically examine the equity-based competencies, including racial attitudes and beliefs, of TFA CMs. We know that TFA CMs are highly educated people willing to work hard to level the field for kids of color and living in poverty (Farr, 2010). What we did not know prior to the podcast, however, is if they exhibit cultural and racial competencies, attitudes, and beliefs. Conversation with stakeholders and TFA-affiliated individuals suggested gaps in key competencies and racial attitudes. This aligns with the finding by Kim, Brewer, and Vasquez Heilig (in press) suggesting that TFA has inculcated Whiteness and White assumptions under the cloak of good intentions, diversity, and culturally relevant teaching. These gaps have implications for the training that $\mathrm{CMs}$ are provided in the name of educational equity and social 
justice and, additionally, raise questions about the kind of education leaders being created postTFA service.

The respondents in the podcast relayed that TFA not only has both a daily and systemic impact at the classroom level — but also a larger systemic impact. TFA is a central and important node in a network promoting the rapid expansion of market-based education, a reform effort that amplifies the voices of an elite network of privately sponsored organizations and individuals, while often disenfranchising the voices of community members and educational professionals. This finding underscored previous research from Kretchmar, Sondel, and Ferrare (2014) that utilized a policy network analysis, to create a visual representation of TFA's key role in developing and connecting personnel, political support, and financial backing to create a powerful network of interdependent organizations and individuals who promote and implement the expansion of charter schools and other market-based reforms. Brewer, Hartlep, and Scott (2018) also found that TFA alumni networks and donors have been a primary ideological and political driving force for privatization and private control of public schools.

Kretchmar, Sondel, and Ferrare (2014) depicted the broad scope of connections within TFA's alumni network and demonstrate that the organization is not only an important actor in education reform policy, but also a preeminent incubator for personnel who leave the classroom after two years (typically) and go on to quickly lead and staff existing and new pro-market reform organizations. As a result, TFA has transformed itself into a recruiting center of progressive-minded individuals for private-control and privatization focused market-based education reform. After TFA, alums are then inculcated into network that has evolved into a basecamp for privatization and private control sympathizers (Kretchmar, Sondel, \& Ferrare, 2014). A cadre of CMs are run through a variety of TFA-affiliated education reform 
organizations (i.e. StudentsFirst, Leadership for Educational Equity, and TNTP) and immediately placed in position of political and educational leadership roles that empower them to organize on behalf of corporate education reform (Scott, Trujillo, \& Rivera, 2016).

In conclusion, the biggest takeaway from the first twelve episodes of the Truth for America podcast is that given the rapid expansion of education reform, driven in part by the strategic and extensively funded TFA network outlined by respondents, it is readily apparent how the organization is influencing policy decisions that are being made at the federal, state and local levels. While TFA's network is intricately connected, politically powerful, and rhetorically committed to "equity and justice," the actual impact of their promoted education reform policies on students and communities must continue to be evaluated with a critical eye for the actual impact that the organization is having on students, teachers, CMs, schools, and education policy across the United States and world. 


\section{References}

Anderson, A. (2013a). Teach For America and symbolic violence: A Bourdieuian analysis of education's next quick-fix. Urban Review, 46(1), 77-91.

Anderson, A. (2013b). Teach For America and the dangers of deficit thinking. Critical Education, 4(11), 1-20.

Angrosino, M. (2008). Doing ethnographic and observational research. London, UK: SAGE Publications.

Blanc, L. (2016, Jun 17). TFA out in San Francisco. On Truth for America [Podcast]. Retrieved from https://itunes.apple.com/us/podcast/truth-for-america/id1086793972?mt=2

Borgatti, S. (2005). Introduction to grounded theory. Retrieved from http://www.analytictech.com/mb870/introtoGT.htm

Brewer, T. J. (2014a). Accelerated burnout: How teach for America's academic impact model and theoretical framework can foster disillusionment among its corps members. Educational Studies, 50(3), 246-263.

Brewer, T. J. (2014b). How Teach For America affects the training and effectiveness of classroom instructors. Retrieved from Cambridge, MA: http://www.scholarsstrategynetwork.org/sites/default/files/ssn_basic_facts_brewer_on_te ach_for_america2.pdf

Brewer, T. J. (2016a). An examination of teach for america's impact on the teaching profession, hiring practices, and educational leadership. (Ph.D. Dissertation), University of Illinois at Urbana-Champaign, Champaign, IL. Retrieved from http://hdl.handle.net/2142/90541

Brewer, T. J. (2016b, March 18). Not Special Education. On Truth For America [Podcast]. Retrieved from https://itunes.apple.com/us/podcast/truth-for- 
$\underline{\text { america/id1086793972? } \mathrm{mt}=2}$

Brewer, T. J., \& Cody, A. (2014). Teach For America: The neoliberal alternative to teacher professionalism. In J. A. Gorlewski, B. Porfilio, D. A. Gorlewski, \& J. Hopkins (Eds.), Effective or wise? Teaching and the meaning of professional dispositions in education(pp. 77-94). New York, NY: Peter Lang.

Brewer, T. J., deMarrais, K., \& McFaden, K. (Eds.). (2020). Teach For All counter-narratives: International perspectives on a global reform movement.

Brewer, T. J., Hartlep, N. D., \& Scott, I. (2018). Forbes 30 under 30 in education: Manufacturing “edu-preneur" networks to reinforce privatization/marketization. Educational Policy Analysis Archives.

Brewer, T. J., Kretchmar, K., Sondel, B., Ishmael, S., \& Manfra, M. (2016). Teach for America's preferential treatment: School district contracts, hiring decisions, and employment practices. Educational Evaluation and Policy Analysis, 24(15), 1-38.

Brooks, E., \& Greene, K. (2013). Problems, politics, and possibilities: Imagining a Teach For America that really is for America. Critical Education, 4(13), 68-92.

Cersonsky, J. (2013). The hidden truth behind Teach For America's political empire. Retrieved from http://www.salon.com/2013/09/17/the_truth_behind_teach_for_americas_political_empir e/

Charmaz, K. (2005). Grounded theory in the 21st century: A qualitative method for advancing social justice research. In N. K. Denzin \& Y. S. Lincoln (Eds.). The Sage handbook of qualitative research ( $3^{\text {rd }}$ Ed.), (pp. 507-535). Thousand Oaks, CA: Sage Publications Inc. 
Clark, M. A., Isenberg, E., Liu, A. Y., Makowsky, L., \& Zukiewicz, M. (2015).Impacts of the Teach For America investing in innovation scale-up. Mathematica Policy Research, Princeton.

Coles, R., \& Thomson, P. (2016). Beyond records and representations: Inbetween writing in educational ethnography. Ethnography and Education, 11(3), 253-266.

Crawford-Garrett, K. (2013). Teach For America and the struggle for urban school reform. New York, NY: Peter Lang.

Darling-Hammond, L. (1994). Who will speak for the children? How "Teach for America" hurts urban schools and students. Phi Delta Kappan, 76(1), 21-34.

Darling-Hammond, L., Holtzman, D. J., Gatlin, S. J., \& Vasquez Heilig, J. (2005). Does teacher preparation matter? Evidence about teacher certification, Teach For America, and teacher effectiveness. Does teacher preparation matter? Evidence about teacher certification, Teach For America, and teacher effectiveness. Education Policy Analysis Archives, 13(42).

Dell'Angela, T. (2016a). Hey TFA haters, what's wrong with a little idealism? Retrieved June 1, 2018 from http://educationpost.org/hey-tfa-haters-whats-wrong-with-a-little-idealism/ Dell'Angela, T. (2016b, Feb 8). Debating Ed Post. On Truth For America [Podcast]. Retrieved from https://itunes.apple.com/us/podcast/truth-for-america/id1086793972?mt=2

Delgado, R. \& Stefancic, J. (2012). Critical race theory. (2 ${ }^{\text {nd }}$ ed.). New York, NY: New York University Press.

deMarrais, K., Lewis, J., \& Wenner, J. (2013). Bringing Teach For America into the forefront of teacher education: Philanthropy meets spin. Critical Education, 4(11), 1-26. 
Dicks, B., Soyinka, B., \& Coffey, A. (2006). Multimodal ethnography. Qualitative research, 6(1), 77-96.

Farr, S. (2010). Teaching as leadership: The highly effective teacher's guide to closing the achievement gap. San Francisco, CA: Jossey-Bass.

Geertz, C. (1973). The interpreation of cultures. New York, NY: Basic Books.

Geertz, C. (1988). Works and lives: The anthropologist as author. Stanford, CA: Stanford University Press.

Giroux, H. (1996). Counternarratives: Cultural studies and critical pedagogies in postmodern spaces. New York: Routledge.

Glaser, B. (1992). Basics of grounded theory analysis. Mill Valley, CA: Sociology Press.

Glazerman, S., Mayer, D., \& Decker, P. (2006). Alternative routes to teaching: The impacts of Teach For America on Student Achievement and other outcomes. Journal of Policy Analysis and Management 25(1), 75-96.

Gutmann, L. (2013). The outsized effects of equating teaching with leadership: Implication of Teach For America's vision for engaging teachers in reform. Critical Education, 4(13), 45-68.

Hagopian, J. (2016, April 18). Racism? Diversity? On Truth For America [Podcast]. Retrieved from https://itunes.apple.com/us/podcast/truth-for-america/id1086793972?mt=2

Hartman, A. (2011). Teach For America: The hidden curriculum of liberal do-gooders. Jacobin. Retrieved from https://www.jacobinmag.com/2011/12/teach-for-america

Heinike, A. J., \& Cameron, Q. (2011). Closing the classroom door and the achievement gap: Teach For America alumni teachers' appropriation of Arizona language policy. Education and Urban Society, 45(4), 483-505. 
Horn, J. (2011). Corporatism, KIPP, and cultural eugenics. In P. E. Kovacs (Ed.), The Gates foundation and the future of U.S. "public" schools (pp. 80-103). New York, NY: Routledge.

Howland-Bolton, E. (2016, Jul 13). SOS LIVE in DC. On Truth For America [Podcast]. Retrieved from https://itunes.apple.com/us/podcast/truth-foramerica/id1086793972? $\mathrm{mt}=2$

Joseph, G. (2014). This is what happens when you criticize Teach For America: An internal memo reveals how TFA's obsessive PR game covers up its lack of results in order to justify greater expansion. Retrieved from http://www.thenation.com/article/186481/whathappens-when-you-criticize-teach-america

Kim, A. (2016, Apr 22). Ravitch et al. LIVE. On Truth For America [Podcast]. Retrieved from https://itunes.apple.com/us/podcast/truth-for-america/id1086793972?mt=2

Kim, A., Brewer, T. J. \& Vasquez Heilig, J. (in press). Planting toxic seeds in fertile soil: The knowledge acquisition, achievement, and behavioral beliefs inculcated into Teach For America corps members of color. In C. Gist and T. Bristol (Eds.), Handbook of Research on Teachers of Color (pp. XX-XXX). Washington, DC: American Educational Research Association.

Kopp, W. (2011). A chance to make history: What works and what doesn't in providing an excellent education for all. New York: Public Affairs.

Kretchmar, K., Sondel, B., \& Ferrare, J. (2014) Mapping the terrain: Teach For America, Charter school reform, and corporate sponsorship. Journal of Education Policy, 29(6), p. 742759. 
Kwock Hu, L. A. (2009). A case study of one Teach For America corps member's use of equity pedagogy (Doctoral dissertation). University of Southern California, Los Angeles, CA.

La Londe, P., Brewer, T. J., \& Lubienski, C. (2015). Teach For America and teach for all: Creating an intermediary organization network for global education reform. Education Policy Analysis Archives, 23(47), 1-28.

Labaree, D. (2010). Teach For America and teacher ed: Heads they win, tails we lose. Journal of Teacher Education, 61(1-2), 48-55.

Laczko-Kerr, I., \& Berliner, D. C. (2002). The effectiveness of "Teach For America" and other under-certified teachers on student academic achievement: A case of harmful public policy. Education Policy Analysis, 10(37).

Lahann, R., \& Reagan, E. M. (2011). Teach For America and the politics of progressive neoliberalism. Teacher Education Quarterly, 38(1), 7-27.

Matsui, S. (2015). Learning from counternarratives in Teach For America: Moving from idealism towards hope. New York, NY: Peter Lang.

McCarthy, C. (1998). The uses of culture: Education and the limits of ethnic affiliation. New York, NY: Routledge.

Marta (2016, Jan 13). Principal Speaks. On Truth for America [Podcast]. Retrieved from https://itunes.apple.com/us/podcast/truth-for-america/id1086793972?mt=2

Muñoz, C. Vasquez Heilig, J \& Del Real, M. (2019) Property functions of Whiteness: Counternarrative analysis of Teach For America and their partnership with Black and Latinx fraternities and sororities. In K. Gillion, C. Beatty, \& C. Salinas (Eds.), New directions 
for student affairs: Critical considerations of race, ethnicity, and culture in fraternity/sorority life, (61-71) San Francisco: Jossey-Bass Publishing.

Murthy, D. (2008). Digital ethnography: An examination of the use of new technologies for social research. Sociology, 42(5), 837-855.

Nieto, S. (1999). The light in their eyes: Creating multicultural learning communities. New York: Teachers College Press.

Patton, M. Q. (1990). Qualitative evaluation and research methods (2nd ed.). Newbury Park, CA: Sage.

Pew Research Center. (June, 2016). "State of the News Media 2016” Available from https://assets.pewresearch.org/wp-content/uploads/sites/13/2016/06/30143308/state-ofthe-news-media-report-2016-final.pdf

Popkewitz, T. (1995). Policy, knowledge, and power: Some issues for the study of educational reform. Transforming Schools, 413-455.

Popkewitz, T. S. (1998). Struggling for the soul: The politics of schooling and the construction of the teacher. New York: Teachers College Press.

Rapley, T. (2009). Doing conversation, discourse and document analysis. London: SAGE Publications.

Ravitch, D. (2016, Apr 22). Ravitch et al. LIVE. On Truth For America [Podcast]. Retrieved from https://itunes.apple.com/us/podcast/truth-for-america/id1086793972?mt=2

Rebecca (2016, Mar 18). Not Special Education. On Truth For America [Podcast]. Retrieved from https://itunes.apple.com/us/podcast/truth-for-america/id1086793972?mt=2

Reckhow, S. (2013). Follow the money: How foundation dollars change public school politics. Oxford: Oxford University Press. 
Reckhow, S., \& Snyder, J. (2014). The expanding role of philanthropy in education politics. Educational Researcher, 43(186), 186-195.

Renee v. Duncan, (20120). 623 F. 3d 787 (9th Circuit 2010)

Ruiz Bybee, E. (2013). An issue of equity: Assessing the cultural knowledge of preservice teachers in Teach For America. Critical Education, 4(13), 28-44.

Schneider, M. (2017). Peter Cunningham's Education Post chaperoned by Broad foundation. Retrieved from https://deutsch29.wordpress.com/2017/10/13/peter-cunninghamseducation-post-chaperoned-by-broad-foundation/

Scott, I. (2017, Feb 27). Charters and Special Education. On Truth For America [Podcast]. Retrieved from https://itunes.apple.com/us/podcast/truth-for$\underline{\text { america/id1086793972? } \mathrm{mt}=2}$

Sommer, C. (2014). Teach For America's pro-corporate, union-busting agenda. Retrieved from http://www.salon.com/2014/01/13/teach_for_americas_pro_corporate_union_busting_ag enda_partner/

Scott, J., Trujillo, T. \& Rivera, M. D. (2016). Reframing Teach For America: A conceptual framework for the next generation of scholarship. Education Policy Analysis Archives, 24(12), http://dx.doi.org/10.14507/epaa.24 .2419

Stern, M. and Johnston, D. K. (2013). "I want to do Teach For America, not become teacher." Critical Education, 4(13), 1-27.

Teach For All. (n.d.). Global organization. Retrieved from http://www.teachforall.org/ournetwork-and-impact/global-organization

Teach For America. (2012). Who we look for. Retrieved from http://www.teachforamerica.org/why-teach-for-america/who-we-look-for 
Teach For America. (n.d.). Our mission. Retrieved from http://www.teachforamerica.org/our$\underline{\text { mission }}$

Tompkins-Stange, M. 2016. Policy Patrons: Philanthropy, Education Reform, and the Politics of Influence. Cambridge: Harvard Education

Tiffany (2016, Apr 29). TFA first-year experience. On Truth For America [Podcast]. Retrieved from https://itunes.apple.com/us/podcast/truth-for-america/id1086793972?mt=2

Vasquez Heilig, J,. Brewer, T.J. \& White, T. (2018). What Instead?: Reframing the debate about charter schools, Teach For America, and testing. In R. Ahlquist, P. Gorski and T. Montano (Eds.), Assault on Kids and Teachers: Countering privatization, deficit ideologies and standardization of U.S. schools, (pp. 201-217) New York: Peter Lang.

Vasquez Heilig, J., Cole, H. \& Springel, M. (2011). Alternative certification and Teach For America: The search for high quality teachers. Kansas Journal of Law and Public Policy, 20(3), 388-412.

Vasquez Heilig, J. \& Jez, S. (2010). Teach For America: A review of the evidence. Boulder, CO: National Education Policy Center, University of Colorado.

Vasquez Heilig, J. \& Jez, S. (2014). Teach For America: A return to the evidence. Boulder, CO: National Education Policy Center, University of Colorado.

Veltri, B. T. (2008). Teaching or service? The site-based realities of Teach For America teacher in poor, urban schools. Education and Urban Society, 40(5), 511-542.

Veltri, B. T. (2010). Learning on other people's kids: Becoming a Teach For America teacher. Charlotte, NC: Information Age Publishing.

Veltri, B. T. (2012). Teach For America: It's more about leading than teaching. Educational Leadership, 69(8), 62-65. 
White, T. (2016, April 18). Racism? Diversity? [Podcast]. Truth For America. Retrieved from https://itunes.apple.com/us/podcast/truth-for-america/id1086793972?mt=2

Willens, M. (2015). Americans listen to 21 million hours of podcasts every day, cutting into radio, research finds. Retrieved from http://www.ibtimes.com/americans-listen-21$\underline{\text { million-hours-podcasts-every-day-cutting-radio-research-finds-179281 }}$

Wirth, L (2017, Nov 22). Lawsuit: TFA not interested in equity and access. On Truth For America [Podcast]. Retrieved from https://itunes.apple.com/us/podcast/ep-16-lawsuit-tfanot-interested-in-equity-access-truth/id1086793972? $\mathrm{i}=1000395163401 \& \mathrm{mt}=2$

Zeichner, K. (20, August 27). How the public is deceived about 'highly qualified teachers'. Washington Post. Retrieved from https://www.washingtonpost.com/news/answersheet/wp/2013/08/27/how-the-public-is-deceived-about-highly-qualified-teachers 